\title{
THE EFFECT OF THE CROSS-LINKER CONTENT ON THE SWELLING PROPERTIES OF INTELLIGENT GELS
}

Snežana S. Ilić-Stojanović1 ${ }^{\star}$, Ljubiša B. Nikolić ${ }^{1}$, Vesna D. Nikolić1,

Slobodan D. Petrović ${ }^{2}$, Aleksandar S. Zdravković ${ }^{3}$, Jakov V. Stamenković ${ }^{1}$

1 University of Niš, Faculty of Technology, Leskovac, Serbia

2University of Belgrade, Faculty of Technology and Metallurgy, Belgrade, Serbia

${ }^{3}$ College of Textile, Leskovac, Serbia

This paper presents the procedure for the synthesis of hydrogels based on $\mathrm{N}$ isopropylacrylamide (NIPAM) and 2-hydroxypropyl methacrylate (HPMet) using dioxan as a solvent. Hydrogels were obtained by radical polymerization using different contents of ethylene glycol dimethacrylate as a cross-linker and benzoyl peroxide as the initiator. In the FTIR spectra of poly $(N$-isopropylacrylamide-co2-hydroxypropylmethacrylate) (p(NIPAM-HPMet)) xerogel, new absorption bands are present and there are no specific bands characteristic of a monomer NIPAM, which indicates that copolymerization was performed. SEM micrographs show porous surfaces of xerogels. The aim of this work was the investigation of the swelling behavior for all synthesized hydrogels with different cross-linker content at the temperature from 20 to $40{ }^{\circ} \mathrm{C}$. The sample of $\mathrm{p}$ (NIPAM-HPMet) with the lowest cross-linker content reached the highest swelling degree at $20^{\circ} \mathrm{C}$ $(\alpha=20.23)$. The degree of swelling decreased with increa-sing the cross-linker content and temperature, so the samples with highest cross-linker content at $40{ }^{\circ} \mathrm{C}$ reached the swelling degree of 2.05 .
(ORIGINAL SCIENTIFIC PAPER) UDC 544.773.432:678.7

Keywords: thermo-sensitive hydrogels, hydrogel swelling, $\mathrm{N}$-isopropylacrylamide, 2-hydroxypropyl methacrylate, FTIR spectroscopy, SEM

\section{Introduction}

Hydrogels are two- or multi-component systems consisting of a three-dimensional weak cross-linked network of polymer chains and water, or a fluid that fills the space between macromolecules [1]. A xerogel may be defined as a polymeric network without water. Hydrogels can be obtained from natural polymers or can be synthesized from monomers. Hydrogels based on natural polymers (starch, cellulose, protein, dextran, chitosan, alginate, hyaluronic acid, fibrin, collagen, gelatin) are biocompatible and biodegradable, but do not have good mechanical properties, they may contain pathogenic microorganisms or induce immune-inflammatory response. The structure of synthetic hydrogels may be designed by selecting a monomer and other reactants and also during the process of polymerization reactions in order to achieve desired properties for a specific application.

Conventional hydrogels show no sensitivity to changes in the external environment, while stimuli sensitive hydrogels show a significant change in the volume, shape and mechanical properties due to changes in the external environment [2]. Stimuli sensitive hydrogels have the ability to swell and de-swell in accordance with the environment conditions, which puts them in a group of new "intelligent" materials. Hydrogels may be sensitive to one or more environmental factors which depends on their composition and structure. Environmental factors may be physical (temperature, pressure, light, electric or magnetic field, etc.) and chemical $(\mathrm{pH}$, ionic strength, the presence of certain molecules, etc.) [3]. According to the type of stimulus, the "intelligent" gels can be divided into: thermo-, $\mathrm{pH}-, \mathrm{pH}-$ and temperature, biochemical analytes-, pressure- and ionic strength-, ultrasound-, lightand magnetically-sensitive hydrogels. Thermo-sensitive hydrogels may swell or de-swell as a result of changes in temperature of the surrounding fluid. A common property of all thermo-sensitive hydrogels is the presence of hydrophilic groups: methyl-, ethyl- and propyl- $[4,5]$. According to the critical solution temperature they are classified as: negatively thermo-sensitive, positively thermo-sensitive and thermally reversible gels. Negatively thermo-sensitive hydrogels have a lower critical solution temperature (LCST), which can be defined as the critical temperature below which the polymer swells in the solution, and above which the polymer contracts [6]. Positively thermo-sensitive hydrogels have an upper critical solution temperature (UCST) and upon cooling below the UCST they contract. Thermally reversibile composite copolymers are sensitive to external stimulus, and have the LCST and UCST within different temperature ranges [7]. The $\mathrm{pH}$-sensitive hydrogels have ionizing functional groups. Very small changes in $\mathrm{pH}$ and/ or ionic strength of the medium can cause a significant

\footnotetext{
*Author address: Snežana llić-Stojanović, University of Niš, Faculty of Technology, Bulevar oslobođenja 124, 16000 Leskovac, Serbia

E-mail: ilicsnezana@tf.ni.ac.rs

The manuscript received: May, 5, 2014.

Paper accepted: Jun, 26, 2014.
} 
change in the degree of swelling. According to the nature of the side groups, $\mathrm{pH}$-sensitive hydrogels are classified as: cationic, anionic and amphiphilic.

According to the pore size hydrogels are divided into: superporous (pores $>100 \mu \mathrm{m}$ ), macroporous (pores from 0.1 to $1 \mu \mathrm{m}$ ), microporous (pores between 0.1 and $0.01 \mu \mathrm{m}$ ) and non-porous hydrogels (pores between 0.001 and $0.01 \mu \mathrm{m}$ ), as well as the number of other divisions [8].

Hydrogels sensitive to changes in $\mathrm{pH}$ - and the temperature of surrounding medium are important for human application if they function at physiologically relevant temperatures, $\mathrm{pH}$ and ionic strength. Stimuli, such as a magnetic or electric field, ultrasound, radiation or electrical effects may trigger the release of some therapeutic molecule, previously incorporated in the hydrogel [5].

When the dry sample of the hydrogel comes in contact with water, the molecules of water penetrate into the polymer network and induce the increase in the volume and swelling of the network [9]. The water, which in this way reaches the hydrogel, is called "primary bound water". This leads to the expansion of the polymer chains<smiles>C=CC(=O)NC(C)C</smiles>

and during the process the hydrophobic groups are in contact with water molecules too. The "interstitial water" is the type of water which is not attached to hydrogels network, but physically trapped in between the hydrated polymer chains [10]. The "bound water" is attached to the polymer chain through the hydration of functional groups or ions. "Semi-bound water" is a type of water with intermediate properties of a "bound water" and "free water".

The aim of this work was the synthesis of hydrogels based on $\mathrm{N}$-isopropylacrylamide (NIPAM) and 2-hydroxypropyl methacrylate (HPMet) with different contents of ethylene glycol dimethacrylate as a cross-linker by free radical copolymerization, their characterization by using Fourier transform infrared (FTIR) spectroscopy, scanning electron microscopy (SEM) and the effect of the crosslinker content on the swelling behavior. The structural formula of the used monomers $\mathrm{N}$-isopropilcrylamide and 2-hydroxypropyl methacrylate and the potential structure of the synthesized copolymer were presented in Figure 1. This work presents a continuation of the extensive investigation of "intelligent" gels based on NIPAM [11-13].

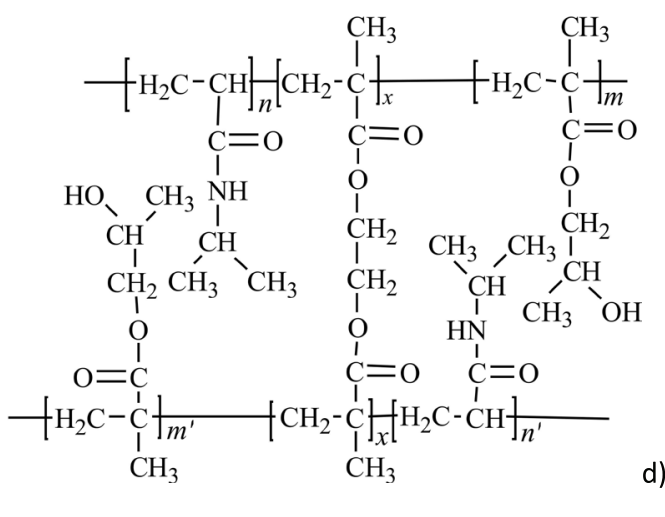

Figure 1. Structural formula of: a) $N$-isopropiycrylamide, b) 2-hydroxypropyl methacrylate, c) ethylene glycol dimethacrylate and d) potential copolymer structure

\section{Experimental}

\section{Reagents}

$\mathrm{N}$-isopropylacrylamide (NIPAM) 99\%, (Acros Organics, New Jersey, SAD), 2-hydroxypropyl methacrylate (Acros Organics, New Jersey, SAD) 96,5\%, ethylene glycol dimethacrylate (EDGM) (Fluka, Chemical Corp, $\mathrm{CH}$ ), 97\%, benzoyl peroxide, BP, (Fluka, Chemical Corp, $\mathrm{CH}$ ) 98\%, 1,4-dioxan, DX, 99,0\% (Centrohem, Beograd, RS) 99,5\%, methanol, 99,9\% HPLC grade (Chromasolv, Sigma-Aldrich Chemie $\mathrm{GmbH}$, DE) i $99,5 \%$ p.a. (Centrohem, Beograd, RS).

\section{Synthesis of $p($ NIPAM-HPMet) hydrogels}

Transverse cross-linked random copolymers of NIPAM with $10 \mathrm{~mol} \%$ of HPMet were synthesized by using EDGM as cross-linking agent (the concentration of which varied: $1 \mathrm{~mol} \%, 1.5 \mathrm{~mol} \%, 2 \mathrm{~mol} \%$ and $3 \mathrm{~mol} \%$ ), and benzoyl peroxide used as the initiator in dioxane as a solvent. The amounts of the reactants used for the synthesis of hydrogels are shown in Table 1.

Table 1: The amounts of the reactants used for the hydrogels synthesis

\begin{tabular}{cccccc}
\hline EGDM (mol\%) & NIPAM $(\mathbf{m g})$ & HPMet $(\mathbf{m g})$ & EGDM $(\mathbf{m g})$ & BP $(\mathbf{m g})$ & $\mathbf{D X}\left(\mathbf{c m}^{3}\right)$ \\
\hline 1 & 650 & 82,8 & 12,5 & 20 & 0,75 \\
1,5 & 650 & 82,8 & 18,8 & 20 & 0,75 \\
2 & 650 & 82,8 & 25,1 & 20 & 0,75 \\
3 & 650 & 82,8 & 37,6 & 20 & 0,75 \\
\hline
\end{tabular}

After dissolution and homogenization of the monomer, the reaction mixture was injected into the glass tube of $5 \mathrm{~mm}$ internal diameter. The tubes, with the reaction mixture, were fused and polymerization was performed for 75 minutes at $120^{\circ} \mathrm{C}$. The obtained cylindrical hydrogels of $p$ (NIPAM-HPMet) were separated from the glass tube 
after cooling. The extraction of the unreacted monomer was performed with $50 \mathrm{ml}$ of $100 \%$ methanol for 3 days after polymerization. Swollen gels were then chopped into smaller disks and dried at $40{ }^{\circ} \mathrm{C}$ for 2 hours and then stored in a desiccator.

Characterization of the $p$ (NIPAM-HPMet) xerogels

Fourier transform infrared spectroscopy (FTIR)

For recording FTIR spectra, the potassium bromide technique was used for preparing a solid sample. In order to obtain a thin transparent pastille, the mixture of $1 \mathrm{mg}$ sample and $150 \mathrm{mg} \mathrm{KBr}$ spectroscopic purity was subjected to vacuuming and pressing at the pressure of about $200 \mathrm{MPa}$. FTIR spectra of the samples were recorded on a BOMEM MB-100 (Hartmann \& Braun, Canada) in the wavelength range of $4000-400 \mathrm{~cm}^{-1}$.

\section{Scanning electron microscopy (SEM)}

The morphology of xerogels was investigated on a JEOL Scanning Microscope JSM-5300. The samples were first coated by gold/palladium alloy (15/85).

\section{Swelling behavior}

The swelling of $p$ (NIPAM-HPMet) xerogels was carried out in distilled water and monitored gravimetrically by weighing the samples at regular time intervals until the equilibrium was achieved, ie. to the constant mass at the temperature of 20 and $40{ }^{\circ} \mathrm{C}$. The swelling ratio, $\alpha$, was calculated according to the equation 1 :

$$
\alpha=\frac{\mathrm{m}-\mathrm{m}_{0}}{\mathrm{~m}_{0}}
$$

where $m_{0}$ - is the mass of xerogel, and $\mathrm{m}$ - is the mass of the swollen gel at time $t$.

\section{Results and discussion}

A series of copolymers of NIPAM with $10 \mathrm{~mol} \%$ of 2-hydroxypropyl methacrylate was synthesized by using EGDM as the cross-linking agent in dioxane as a solvent. The influence of the cross-linker content, the concentration of which varied from 1, 1.5, 2, and 3 mol\% EGDM relative to the total weight of the reactants was investigated.

The FTIR spectrum of the synthesized hydrogel in the dry state (i.e. xerogel) p(NIPAM-HPMet), with $10 \mathrm{~mol} \%$ of the comonomer HPMet and $3 \mathrm{~mol} \%$ of the cross-linker EDGM is shown in Figure 2. The hydrogel synthesis was carried out by initiating radicals formed by the decomposition of benzoyl peroxide, and the absorption which originated from double $\mathrm{C}=\mathrm{C}$ bond in the FTIR spectrum of xerogel is not present. $\mathrm{N}-\mathrm{H}$ and $\mathrm{O}-\mathrm{H}$ groups in the polymer chains are present as side groups. In the FTIR spectrum a broad band in the range of $3100-3600 \mathrm{~cm}^{-1}$ is observed, with the maximum absorption at $3444 \mathrm{~cm}^{-1}$ which originates from the valence vibrations of $\mathrm{OH}$ groups, $\mathrm{v}(\mathrm{O}-\mathrm{H})$, and the maximum at $3290 \mathrm{~cm}^{-1}$, which originates from the valence vibrations of $\mathrm{N}-\mathrm{H}$ groups, $\mathrm{v}(\mathrm{N}-\mathrm{H})$. Also, there is a band which originates from $\mathrm{C}=\mathrm{O}$ bond of amide (amide band I) at $1651 \mathrm{~cm}^{-1}$, and the band from valence vibrations of $C=O$ bond, $v(C=O)$, of ester at $1728 \mathrm{~cm}^{-1}$. The absorption bands which are the result of $\mathrm{C}-\mathrm{H}$ bond valence vibrations of methyl and methylene groups occur in the range of $2800-3000 \mathrm{~cm}^{-1}$. The absorption bands which originate from in-plane deformation vibrations, $\delta(\mathrm{OH})$ and $\delta(\mathrm{NH})$, with maxima at $1459 \mathrm{~cm}^{-1}$ and at $1548 \mathrm{~cm}^{-1}$ confirm the presence of $\mathrm{NH}$ and $\mathrm{OH}$ groups, respectively, in the copolymer structure. The band which originates from symetric $\mathrm{C}-\mathrm{O}$ valence vibration, $\mathrm{v}_{\mathrm{sym}}(\mathrm{C}-\mathrm{O})$, a peak at $1172 \mathrm{~cm}^{-1}$ is presented in the spectrum of the copolymer. The FTIR spectrum of $p$ (NIPAM-HPMet) shows differences in comparison to the FTIR spectrum of the monomer

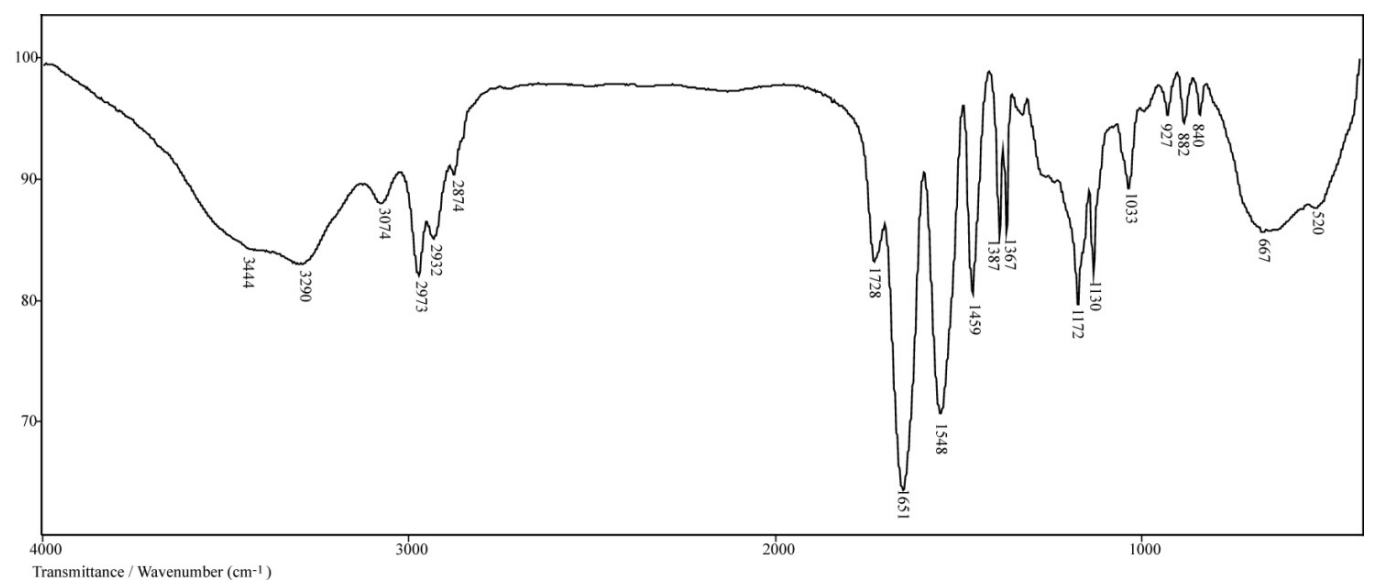

Figure 2. The FTIR spectrum of xerogel p(NIPAM-HPMet) with $10 \mathrm{~mol} \%$ of HPMet and $3 \mathrm{~mol} \%$ of EGDM

SEM micrographs of the synthesized samples of $\mathrm{p}(\mathrm{NIPAM}-\mathrm{HPMet})$ in the xerogel state with $1 \mathrm{~mol} \%, 1.5 \mathrm{~mol} \%$ and $2 \mathrm{~mol} \%$ and $3 \mathrm{~mol} \%$ of EGDM are shown in Figure 3. 
a)

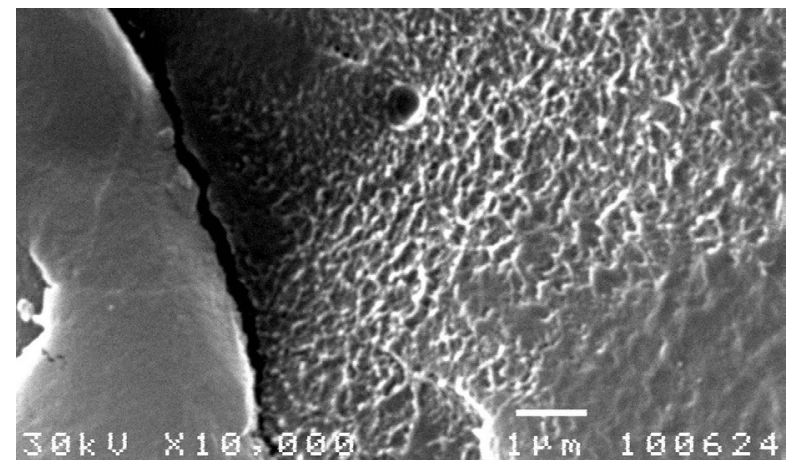

c)

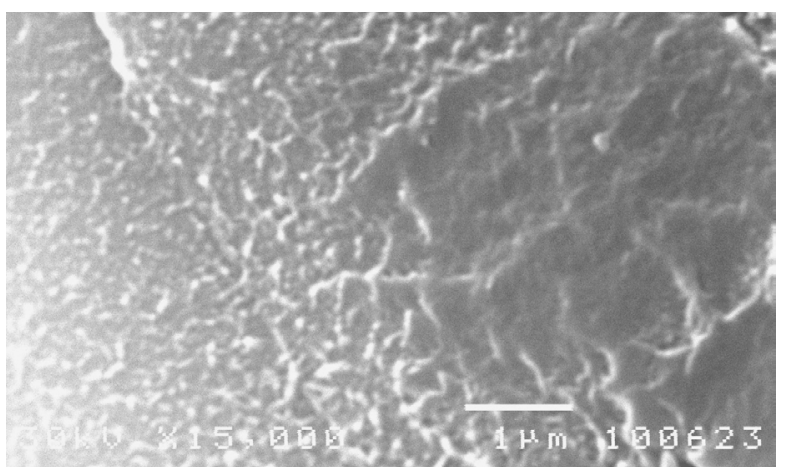

b)

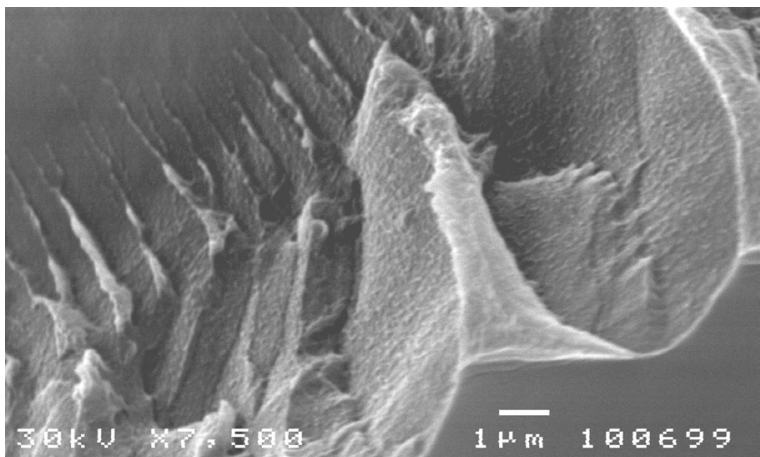

d)

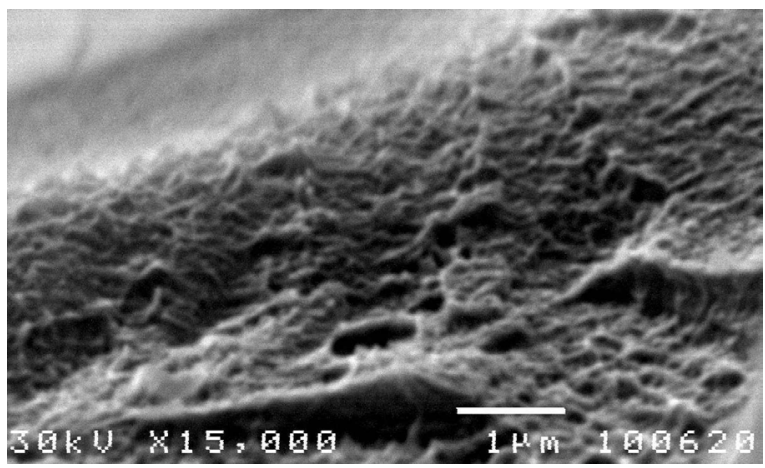

Figure 3. SEM micrographs of p(NIPAM-HPMet) xerogel samples with: a) $1 \mathrm{~mol} \%$ of EGDM (magnification $\times 10000$, bar $=1 \mu \mathrm{m}$ ), b) $1,5 \mathrm{~mol} \%$ of EGDM (magnification $\times 7500$, bar $=1 \mu \mathrm{m}$ ), c) $2 \mathrm{~mol} \%$ of EGDM (magnification $\times 15000$, bar $=1 \mu \mathrm{m}, \mathrm{d}$ ) $3 \mathrm{~mol} \%$ of EGDM (magnification $\times 15000$, bar $=1 \mu \mathrm{m}$ )

The observed morphology of $p$ (NIPAM-HPMet) xerogel has a porous surface. In the SEM micrographs a disordered structure is observed, as well as the presence of a large number of pores and cracks on the surface of the dried gels. The increase of the content of the crosslinking agent caused the reduction of the average pore size. The topography of the copolymer surface indicates the existence of cracks and defects. The surface defects in the form of cracks and channels can be seen in Figures 3 $\mathrm{c}$ and $\mathrm{d}$. The pore size in the sample with $1 \mathrm{~mol} \%$ EGDM is in the range of about $0.1 \mu \mathrm{m}$ to about $0.5 \mu \mathrm{m}$, and the copolymers of $p$ (NIPAM-HPMet) can be classified as macroporous. The pores of the sample with 2 and 3 mol\% EGDM (Figure $3 \mathrm{c}$ and d, respectively) are slightly smaller in average, but without significant differences.

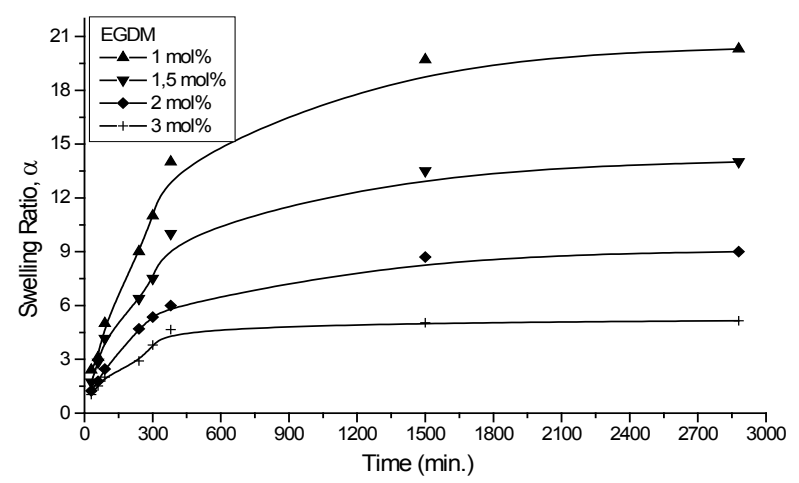

Figure 4. The swelling ratio, $\alpha$, of $p$ (NIPAM-HPMet) hydrogel depending on the time at $20^{\circ} \mathrm{C}$
In Figure 4, the dependence of the degree of swelling, $\alpha$, on time at the temperature of $20^{\circ} \mathrm{C}$ is shown for hydrogels p(NIPAM-HPMet) synthesized with $10 \mathrm{~mol} \%$ of the comonomer HPMet and a different content of the cross-linker EGDM. The change of the degree of swelling depending on the amount of the cross-linker EGDM at $20^{\circ} \mathrm{C}$ is presented in Figure 5.

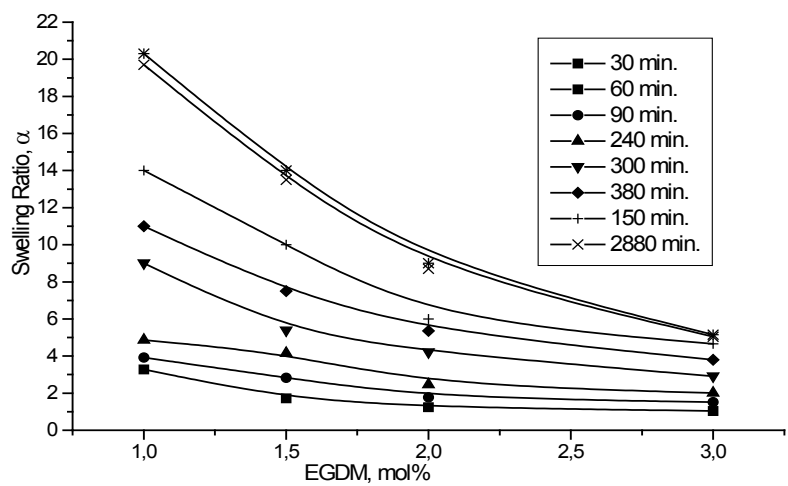

Figure 5. The swelling ratio, $\alpha$, of $p$ (NIPAM-HPMet) depening on the EGDM content at $20^{\circ} \mathrm{C}$

It can be seen that the greatest degree of swelling at a temperature of $20{ }^{\circ} \mathrm{C}$ was reached by hydrogel $\mathrm{p}$ (NIPAM-HPMet) with a minimum content of cross-linker EGDM (1 mol\%) (1 $\mathrm{g}$ of a sample can absorb $20.23 \mathrm{~g}$ of water). The lowest degree of swelling was reached by hydrogel with the highest content of cross-linker EGDM ( $3 \mathrm{~mol} \%$ ), whereby $1 \mathrm{~g}$ of the sample can absorb only 
$4 \mathrm{~g}$ of water. Analysis of the results shows that the degree of swelling decreased with increasing the content of cross-linker EGDM. The decrease in the degree of swelling with cross-linking increase is due to the formation of a denser polymer network that is caused by a greater amount of cross-linker, which leads to less absorption ability of water. In the samples of the hydrogel with a small amount of cross-linker, the length of the polymer chains between two nodes was increased, in which case the polymer network can be more expanded and thus absorbs a larger quantities of water. In comparison to the swelling data published in the literature [12], these results indicate that, after changing the initiator, the solvent and thermal initiation regime, the synthesized hydrogels were reached a lower values of the swelling degree of about $15-30 \%$.

The results of equilibrium swelling of the copolymer hydrogels p(NIPAM-HPMet) dependence on the content of EGDM at a temperature of $40^{\circ} \mathrm{C}$ are shown in Figure 6 .

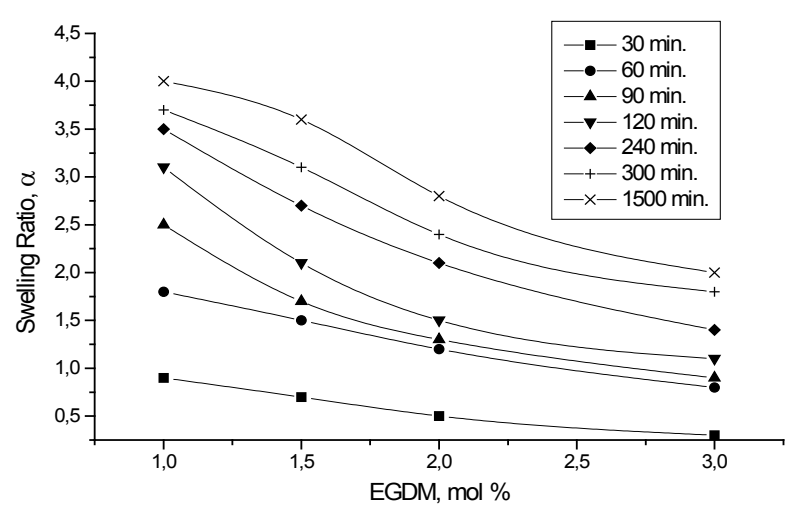

Figure 6. The swelling ratio, $\alpha$, of $p$ (NIPAM-HPMet) depending on the EGDM content at $40^{\circ} \mathrm{C}$

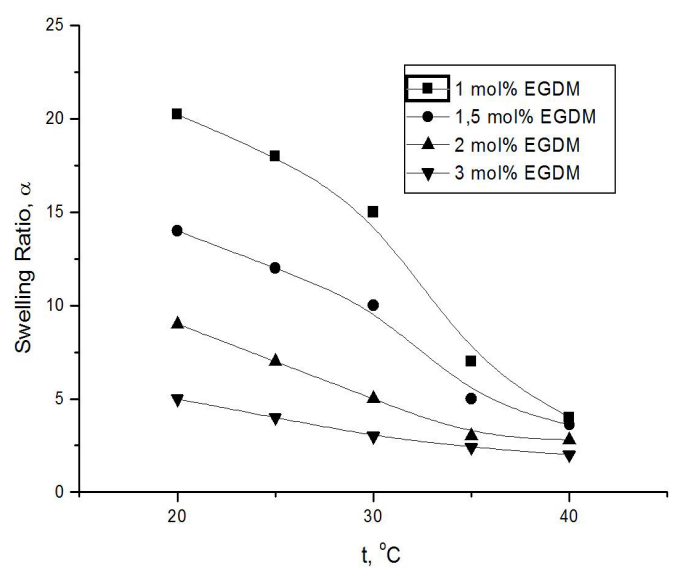

Figure 7. The change of the degree of swelling for $p$ (NIPAMHPMet) with the temperature increase from 20 to $40{ }^{\circ} \mathrm{C}$

It can be seen that the degree of swelling of $p$ (NIPAMHPMet) hydrogels at the temperature of $40^{\circ} \mathrm{C}$ significant- ly decreased in comparison to the swelling properties at $20^{\circ} \mathrm{C}$. Hydrogels with the least content of cross-linker EGDM (1 mol\%) reached the degree of swelling of 4 , and the samples with the highest content of cross-linker (3 mol\%), reached the degree of swelling of 2.05. All samples of hydrogels $p$ (NIPAM-HPMet) showed sensitivity to changes in temperature. The results of the phase transition as a change of degree of swelling for the synthesized p(NIPAM-HPMet) hydrogels with the temperature increase from 20 to $40^{\circ} \mathrm{C}$ are shown in Figure 7 .

The presented results show that the degree of swelling of $p$ (NIPAM-HPMet) hydrogels decreased with the temperature increase to $40^{\circ} \mathrm{C}$, as a result of a phase transition. A visual inspection showed that all synthesized $p$ (NIPAM-HPMet) hydrogels at the lower temperature $\left(20^{\circ} \mathrm{C}\right)$ were swollen, soft and transparent. At $40{ }^{\circ} \mathrm{C}$ p(NIPAM-HPMet) hydrogels became strong, milky white with a reduced swelling capacity because of the phase transition. By the analysis of the presented results it can be concluded that synthesized p(NIPAM-HPMet) hydrogels were thermo-sensitive, which is in accordance with the data published in the literature for the same hydrogels obtained under different conditions, as well as cross linker, initiator, solvent or the method of initiation of polymerization [11-14].

\section{Conclusion}

In this paper, copolymer hydrogels based on NIPAM monomer with $10 \mathrm{~mol} \%$ of the comonomer HPMet were synthesized by using different concentrations of EDGM as a cross-linking agent, and its characterization was performed. The FTIR spectrum of xerogels p(NIPAMHPMet) showed a difference in the structure as compared to the monomer. In the SEM micrographs of xerogels their porous surface was observed. The degree of swelling of hydrogels decreased with increasing the amount of cross-linker EGDM. The highest value of the degree of swelling of hydrogel p(NIPAM-HPMet) was reached with the sample with the lowest content of the crosslinking agent at the temperature of $20^{\circ} \mathrm{C}(1 \mathrm{~g}$ of the sample absorbed $20.23 \mathrm{~g}$ of water). The swelling degree of the synthesized $p$ (NIPAM-HPMet) hydrogels decreased with the temperature increase to $40^{\circ} \mathrm{C}$ as a result of the phase transition, and this indicates that the synthesized hydrogels are thermo-sensitive.

\section{Acknowledgements}

This work was supported by the Ministry of Education, Science and Technological Development of the Republic of Serbia under the project TR-34012.
Abbreviations and symbols
NIPAM - N-isopropylacrylamide
HPMet - 2-hydroxypropyl methacrylate
EGDM - ethylene glycol dimethacrylate 
p(NIPAM-HPMet) - poly $(N$-isopropylacrylamideco-2-hydroxypropyl methacrylate

FTIR - Fourier transform infrared spectroscopy

SEM - scanning electron microscopy

LCST - lower critical solution temperature

UCST - upper critical solution temperature

\section{References}

[1] P. Gupta, K. Vermani, S. Garg, Hydrogels: from controlled release to $\mathrm{pH}$-responsive drug delivery, Drug Discovery Today, 7(10) (2002) 569-579.

[2] N. Kashyap, N. Kumar, M. N. V. Ravi Kumar, Hydrogels for pharmaceutical and biomedical applications. Critical Reviews in Therapeutic Drug Carrier Systems, 22(2) (2005) 107-150.

[3] R. M. Ottenbrite, K. Park, T. Okano, N. A. Peppas, Biomedical Applications of Hydrogels Handbook, Springer, New York, 2010, pp. 432.

[4] Y. Qiu, K. Park, Environment-sensitive hydrogels for drug delivery, Advanced Drug Delivery Review, 53 (2001) 321339.

[5] S. Ilić-Stojanović, Lj. Nikolić, V. Nikolić, S. Petrović, M. Stanković, I. Mladenović-Ranisavljević, Stimuli-sensitive hydrogels for pharmaceutical and medical applications, Facta Universitatis series: Physics, Chemistry and Technology, 9 (1) (2011) 37-56.

[6] J. Heiko, L. Vander, H. Sebastiaan, O. Wonter, B. Piet, Stimulus-sensitive hydrogels and their application in chemical (micro) analysis, The Royal Society of Chemistry, 128 (2003) 325-331.
[7] N. Ohnishi, K. Aoshima, K. Kataoka, K. Ueno, EP 922715. (1999). Agency of industrial science and Technology miti, Tsukuba-shi, Ibaraki (JP)

[8] N. A. Peppas, P. Bures, W. Leobandung, H. Ichikawa, Hydrogels in pharmaceutical formulations, European Journal of Pharmaceutics and Biopharmaceutics, 50 (2000) 27-46.

[9] P. H. Corkhill, A. M. Jolly, C. O. Ng, B.J. Tighe, Synthetic hydrogels: I. Hydroxyalkyl acrylate and methacrylate copolymer-water binding studies, Polymer, 28 (1987) 1758-1766.

[10] H. Omidian, K. Park, in Biomedical Applications of Hydrogels Handbook 1, R.M. Ottenbrite et al. (eds.), Springer Science + Business Media, LLC, 2010, pp. 7.

[11] S. Ilić-Stojanović, Lj. Nikolić, V. Nikolić, S. Petrović, M. Stanković, RS-P-2010/0424 (2010), Belgrade, RS.

[12] S. S. Ilić-Stojanović, Lj. Nikolić, V. Nikolić, M. Stanković, J. Stamenković, I. Mladenović-Ranisavljević, S. Petrović, Influence of monomer and cross-linker molar ratio on the swelling behaviour of thermosensitive hydrogels, Chemical Industry \& Chemical Engineering Quarterly, 18(1) (2012) 1-9.

[13] S. Ilić-Stojanović, Lj. Nikolić, V. Nikolić, I. Ristić, J. BudinskiSimendić, A. Kapor, G. Nikolić,. Structure characterisation of thermosensitive poly( $\mathrm{N}$-isopropylacrylamide-co2-hydroxypropyl methacrylate) hydrogel, Polymer International, PI 4589, on-line first: 23.07.2013.

[14] H. M. Nizam El-Din, Characterization and caffeine release properties of $\mathrm{N}$-isopropylacrylamide/hydroxypropyl methacrylate, copolymer hydrogel synthesized by gamma radiation, Journal of Applied Polymer Sciences, 119(1) (2011) 577-585.

Izvod

\section{EFEKAT SADRŽAJA UMREŽIVAČA NA SVOJSTVA BUBRENJA INTELIGENTNIH GELOVA}

Snežana S. Ilić-Stojanović ${ }^{1}$, Ljubiša B. Nikolić ${ }^{1}$, Vesna D. Nikolić ${ }^{1}$,

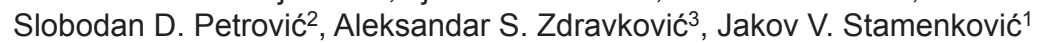

(ORIGINALNI NAUČNI RAD)

1 Univerzitet u Nišu, Tehnološki fakultet, Leskovac, Srbija

2Univerzitet u Beogradu, Tehnološko-Metalurški fakultet, Beograd, Srbija

${ }^{3}$ Visoka strukovna škola za tekstil, Leskovac, Srbija

$\bigcup$ radu je izvršena sinteza hidrogelova na bazi $\mathrm{N}$-izopropilakrilamida (NIPAM) i 2-hidroksipropil metakrilata (HPMet), primenom dioksana kao rastvarača. Hidrogelovi su dobijeni radikalskom polimerizacijom uz upotrebu različitog sadržaja etilenglikoldimetakrilata (EDGM) kao umreživača i benzoil peroksida kao inicijatora. U FTIR spektrima kserogelova poli( $N$-izopropilakrillamid-ko-2-hidroksipropil metakrilata) ( $p($ NIPAM-HPMet)) prisutne su nove apsorpcione trake, a nisu prisutne pojedine trake karakteristične za monomere, što ukazuje na izvršenu kopolimerizaciju. SEM mikrografije pokazuju poroznu površinu kserogelova. Svojstva pri bubrenju svih sintetisanih hidrogelova praćena su na temperaturama od 20 do $40{ }^{\circ} \mathrm{C}$. Najveću sposobnost bubrenja pokazao je uzorak p(NIPAM-HPMet)-a sa najmanjim sadržajem umreživača na $20^{\circ} \mathrm{C}(\alpha=20,23)$. Sposobnost bubrenja opada pri povećanju sadržaja umreživača i temperature, tako da uzorci sa najvećim sadržajem umreživača (3 mol\% EGDM-a) na $40{ }^{\circ} \mathrm{C}$ dostižu stepen bubrenja od samo 2,05.
UDC 544.773.432:678.7

Ključne reči: termoosetljivi hidrogelovi, bubrenje hidrogelova, $\mathrm{N}$-izopropilakrilamid, 2-hidroksipropil metakrilat, FTIR spektroskopija, SEM. 